\title{
Two new species of Archaeohelorus (Hymenoptera, Proctotrupoidea, Heloridae) from the Middle Jurassic of China
}

\author{
Xiaoqing Shi' ${ }^{1, \dagger}$, Yunyun Zhao ${ }^{1, \neq}$, Chungkun Shih ${ }^{1, \S}$, Dong Ren ${ }^{1,1}$ \\ I College of Life Sciences, Capital Normal University, 105 Xisanhuanbeilu, Haidian District, Beijing \\ 100048, China \\ † http://zoobank.org/A799217E-63CF-4EE8-BB7D-3BB4D8A65E0D \\ ¥ http://zoobank.org/C1AE36DE-8D4C-4DA5-BD96-E435A584A5D3 \\ § http://zoobank.org/6FC8E402-B9F2-48B5-B3F2-71B91C09CA7C \\ | http://zoobank.org/D507ABBD-6BA6-43C8-A1D5-377409BD3049 \\ Corresponding author: Dong Ren (rendong@mail.cnu.edu.cn)
}

\begin{tabular}{l}
$\frac{\text { Academic editor: Jes Rust | Received } 4 \text { November } 2013 \mid \text { Accepted } 24 \text { December } 2013 \mid \text { Published } 13 \text { January } 2014}{\text { http://zoobank.org/57D43135-2C67-46A4-BB3A-0A163B5A025D }}$ \\
\hline Citation: Shi X, Zhao Y, Shih C, Ren D (2014) Two new species of Archaeohelorus (Hymenoptera, Proctotrupoidea, \\
Heloridae) from the Middle Jurassic of China. ZooKeys 369: 49-59. doi: 10.3897/zookeys.369.6561
\end{tabular}

\begin{abstract}
Two new fossil species, Archaeohelorus polyneurus sp. n. and A. tensus sp. n., assigned to the genus Archaeohelorus Shih, Feng \& Ren, 2011 of Heloridae (Hymenoptera), are reported from the late Middle Jurassic, Jiulongshan Formation of Inner Mongolia, China. Based on the well-preserved forewings and hind wings of these specimens, the diagnosis of the Archaeohelorus is emended: forewing $2 \mathrm{cu}-\mathrm{a}$ intersecting $\mathrm{Cu}$ and $\mathrm{Rs}+\mathrm{M}$ at the same point or postfurcal, and hind wing may have tubular veins $\mathrm{C}, \mathrm{Sc}+\mathrm{R}, \mathrm{R}, \mathrm{Rs}, \mathrm{M}+\mathrm{Cu}, \mathrm{M}$ and $\mathrm{Cu}$ distinct, or simplified venation. The new findings also elucidate the evolutionary trend of forewing and hind wing venation and body size for the Heloridae from the late Middle Jurassic to now.
\end{abstract}

\section{Keywords}

Fossil wasps, Heloridae, Archaeohelorus, Middle Jurassic, China 


\section{Introduction}

Proctotrupoidea Latreille, 1802, including 11 extant families, is a significant group within Hymenoptera for their long evolutionary history, special morphology and diversity (Grimaldi and Engel 2005). Most extant species of Proctotrupoidea are small wasps except for the giants of the family Pelecinidae (Shih et al. 2010). Heloridae, a small family in Proctotrupoidea, have the earliest fossil records from the late Middle Jurassic (Shih et al. 2011).

Up to date, fossil Heloridae contains 8 genera and 12 species, which have been summarized by Shi et al. (2012). These species have been described from the late Middle Jurassic of Daohugou Ningcheng, China (Shih et al. 2011); the Late Jurassic of Karatau, Russia (Rohdendorf 1938), and of Laiyang, China (Zhang 1992); the Early Cretaceous of Turga, Russia (Rasnitsyn 1990), of Beipiao, China (Zhang and Zhang 2001; Shi et al. 2012); and of Gurvan-Ereny-Nuru, Western Mongolia (Rasnitsyn 1986).

So far, 7 species of Heloridae from China have been reported, including Archaeohelorus hoi Shih, Feng \& Ren, 2011; Gurvanhelorus beipiaoensis Shi, Shih \& Ren, 2012; Protocyrtus validus Zhang \& Zhang, 2001; Sinohelorus elegans Shi, Shih \& Ren, 2012; Spherogaster coronata Zhang \& Zhang, 2001; and Spherogaster saltatrix Shi, Shih \& Ren, 2012.

Extant helorids contains only one genus, Helorus Latreille, 1802, with 12 known valid species mostly in the Holarctic Region. They are parasitoids of larvae of chrysopid lacewings (Neuroptera: Chrysopidae: Chrysopinae: Chrysopa species) (van Achterberg 2006). Among the known species, only Helorus chinensis He, 1992 was described from China (He 1992).

Recently, we collected two well-preserved fossil specimens referable to Heloridae from the late Middle Jurassic Jiulongshan Formation at Daohugou Village, Ningcheng County, Inner Mongolia, China. Based on these new findings, the diagnosis of $\mathrm{Ar}$ chaeohelorus Shih, Feng \& Ren, 2011 is emended and two new species, Archaeohelorus polyneurus sp. n. and A. tensus sp. n., are described. This is the second report of Heloridae in the late Middle Jurassic.

The age of the Daohugou fossil-bearing beds is interpreted to be late Middle Jurassic (ca $165 \mathrm{Ma}$; Ren et al. 2010). This deposit is interpreted to have accumulated in streams and lakes within a humid and warm-temperate climate (Ren et al. 2002). It is rich in well-preserved fossils, especially a high level of insect diversity have been reported including Ephemeroptera (Huang et al. 2008), Odonata (Li et al. 2011), Plecoptera (Liu et al. 2011), Blattodea (Wei et al. 2012), Orthoptera (Gu et al. 2012), Homoptera (Wang et al. 2012), Heteroptera (Lu et al. 2011), Neuroptera (Wang et al. 2010; Shi et al. 2011), Raphidioptera (Engel \& Ren, 2008), Coleoptera (Tan et al. 2012), Mecoptera (Ren et al. 2009; Wang et al. 2012), Hymenoptera (Wang et al. 2012), and Diptera (Liu et al. 2012).

\section{Materials and methods}

All the materials have been collected near Daohugou Village, Shantou Township, Ningcheng County, Inner Mongolia, China; the late Middle Jurassic (Bathonian-Call- 
ovian boundary, $165 \mathrm{Ma}$ ). All fossil specimens are housed in the Key Lab of Insect Evolution \& Environmental Changes, College of Life Sciences, Capital Normal University, Beijing, China.

The specimens were examined dry or under alcohol using a M165 C dissecting microscope (Leica) and are illustrated with the aid of a drawing tube attachment. The figures were drawn by Adobe Photoshop CS5 and CorelDraw 12.0. Morphological terminology and the system used here follow those of Huber and Sharkey (1993) and Rasnitsyn and Zhang (2010).

\section{Systematic Paleontology}

Class Insecta L., 1758

Order Hymenoptera L., 1758

Suborder Apocrita Gerstaecker, 1867

Superfamily Proctotrupoidea Latreille, 1802

Family Heloridae Foerster, 1856

Subfamily Mesohelorinae Rasnitsyn, 1990

Genus Archaeobelorus Shih, Feng \& Ren, 2011

http://species-id.net/wiki/Archaeohelorus

Type species. Archaeohelorus hoi Shih, Feng \& Ren, 2011

Emended diagnosis. Forewing 2cu-a intersecting $\mathrm{Cu}$ and $\mathrm{Rs}+\mathrm{M}$ at the same point or postfurcal. Hind wing may have tubular veins $\mathrm{C}$ and $\mathrm{Sc}+\mathrm{R}$ separated at base, $\mathrm{R}$ developed, $\mathrm{M}+\mathrm{Cu}$ robust and forking at the basal part, $\mathrm{M}$ and $\mathrm{Cu}$ distinct, or simplified venation.

Species included. A. hoi Shih, Feng \& Ren, 2011, A. polyneurussp. n. and $A$. tensus sp. n.

Remarks. This genus was established by Shih et al. 2011 based on a holotype, allotype and six paratypes from the Middle Jurassic of Daohugou, Inner Mongolia, China. Due to lack of discernible hind wings on the fossils of holotype and allotype, the hind wing venation was not described. With the new forewing and hind wing venational information on our new materials, we emended the generic diagnosis.

\section{Archaeobelorus polyneurus sp. $\mathrm{n}$.}

http://zoobank.org/BFECD83C-516A-4F08-BBB3-72A5EB6DFF41

http://species-id.net/wiki/Archaeohelorus_polyneurus

Figures 1, 2

Etymology. The specific name is from Greek word "polyneurus", means "many veins", referring to the complete venation of the hind wing preserved.

Type material. Holotype, CNU-HYM-NN2012052, dorsal view, gender unknown. A well-preserved body with almost complete forewings and hind wings and 

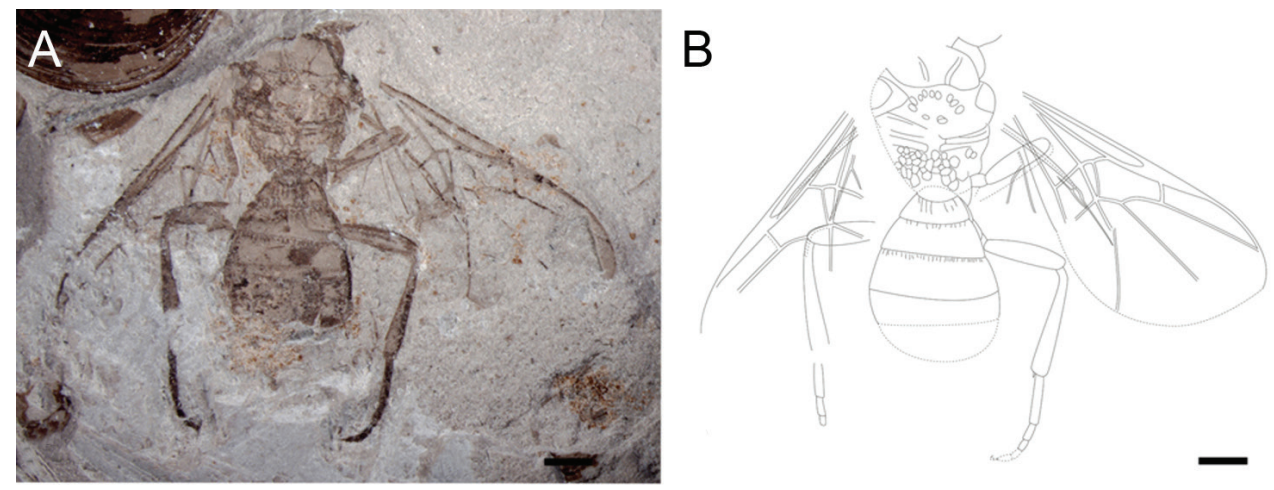

C

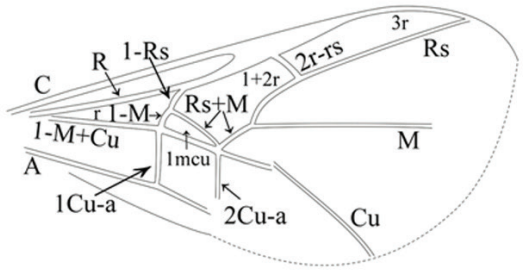

$\mathrm{D}$

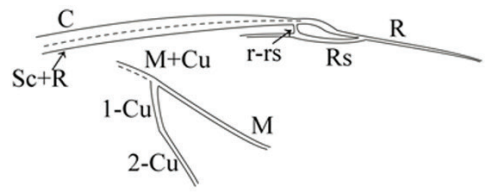

Figure I. Holotype of Archaeohelorus polyneurus sp. n. CNU-HYM-NN-2012052. A Photo B line drawing $\mathbf{C}$ line drawing of forewing $\mathbf{D}$ line drawing of hind wing. Scale bars: $1 \mathrm{~mm}$. (Online figure in color.)

part of legs, but head missing. Paratype: CNU-HY-NN2008010, dorsal view, a wellpreserved almost complete body with forewings and right hind wing and part of legs, previously mis-identified as a paratype of $A$. hoi.

Locality and age. Jiulongshan Formation, Middle Jurassic, Daohugou Village, Shantou Township, Ningcheng County, Inner Mongolia, China.

Diagnosis. In forewing, $2 \mathrm{cu}-\mathrm{a}$ intersecting $\mathrm{Cu}$ and $\mathrm{Rs}+\mathrm{M}$ at the same point and cell $\mathrm{r}$ obtuse-angled triangular (vs. approximately right-angled triangular in $A$. hoi). Hind wing with $\mathrm{S}_{\mathrm{c}+\mathrm{R}}$ confluent with $\mathrm{C}$ and extended to costal margin, $\mathrm{R}$ developed. $\mathrm{M}+\mathrm{Cu}$ distinct and forking at the basal part, $\mathrm{M}$ and $\mathrm{Cu}$ robust.

Remarks. Upon further examination, we found that a paratype of $A$. hoi, CNUHYM-NN2008010, has forewing 2cu-a intersecting $\mathrm{Cu}$ and $\mathrm{Rs}+\mathrm{M}$ at the same point and cell $\mathrm{r}$ obtuse-angled triangular (vs. approximately right-angled triangular in $A$. hoi); and hind wing with tubular vein $\mathrm{C}$ parallel with $\mathrm{Sc}+\mathrm{R}$ at base, $\mathrm{M}+\mathrm{Cu}$ robust and forking at the basal section, $\mathrm{M}$ long, 1-Cu, 2-Cu distinct. These venational characters are consistent with the diagnostic characters of $A$. polyneurus sp. n., hence we transfer CNU-HYM-NN2008010 as a paratype of $A$. polyneurus sp. n.

Description of holotype. A medium-sized body with both forewings and hind wings well-preserved, but, without head (Fig. 1). Forewing broad. Mesosoma suboval, nearly 1.35 times as long as wide; mesoscutum trapezoidal with notauli distinct and 

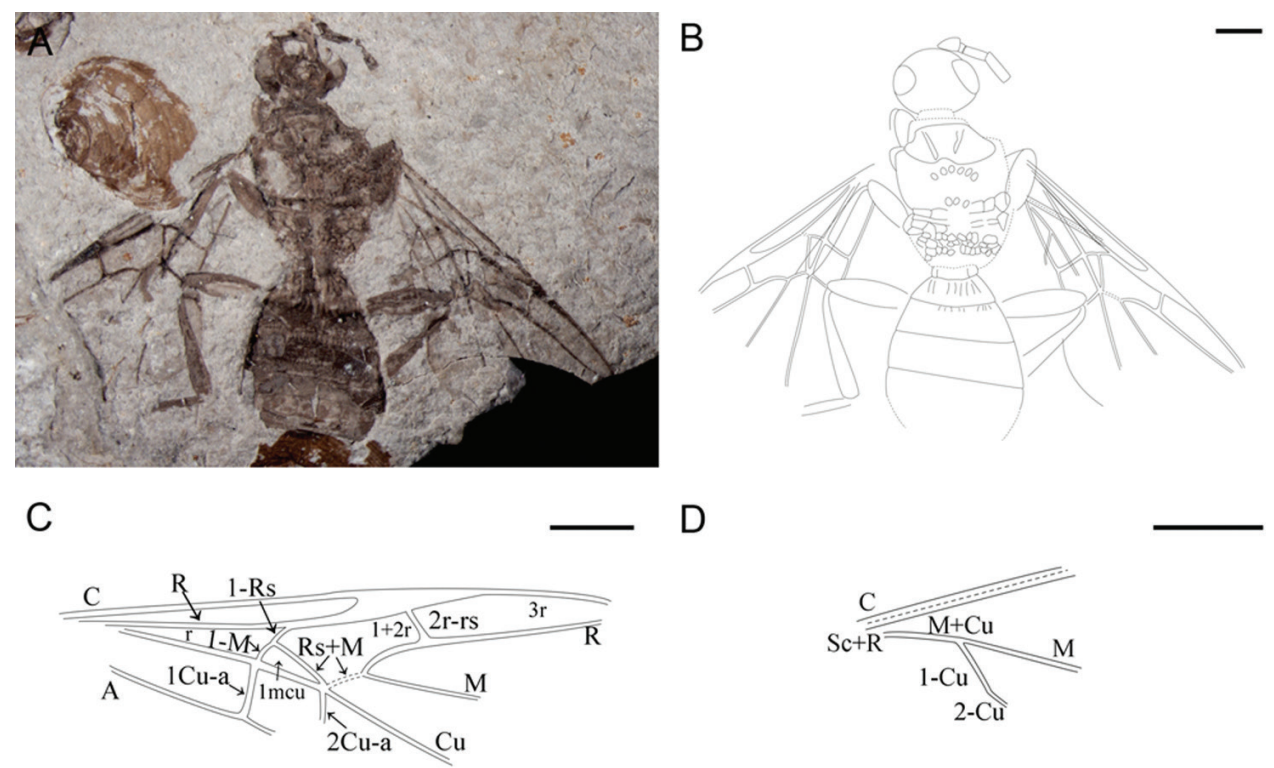

Figure 2. Paratype of Archaeohelorus polyneurus sp. n. CNU-HYM-NN-2008010. A Photo B line drawing $\mathbf{C}$ line drawing of forewing $\mathbf{D}$ lLine drawing of hind wing. Scale bars: $1 \mathrm{~mm}$. (Online figure in color.)

concave; tegula triangular; scutellum broad with two rows of pits; metanotum relatively wide with plenty of pits; propodeum transverse, 2.89 times as broad as long.

Metasoma suboval with six segments; first metasomal segment transverse, second segment with several longitudinal ridges; third and fourth segments trapezoidal with shorter longitudinal ridges anteriorly; other ones smooth; the end of terminal segment not preserved.

Forewing broad and subtriangular. Pterostigma long and acute apically, not widened beyond mid-length. C robust and extending to apex of forewing. $2 \mathrm{r}$-rs arising from basal one third of pterostigma, slightly oblique apicad, slightly longer than pterostigmal width. $\mathrm{R}$ robust, cell $\mathrm{r}$ obtuse-angled triangular and closed by $\mathrm{R}, \mathrm{M}+\mathrm{Cu}, 1-\mathrm{Rs}$ and $1-\mathrm{M}$; Rs straight and intersecting with distal part of $\mathrm{C}$. Cell $1+2 \mathrm{r}$ six-sided and surrounded by $\mathrm{R}, 1-\mathrm{Rs}, 1-\mathrm{Rs}+\mathrm{M}, 2-\mathrm{Rs}+\mathrm{M}, 2-\mathrm{Rs}$, and 2r-rs. $\mathrm{M}+\mathrm{Cu}$ straight and distinct; $\mathrm{M}$ and $\mathrm{Cu}$ distinct, $\mathrm{M}$ straight, $\mathrm{Cu}$ break after $1 \mathrm{~m}$-cu. 1-Rs as long as 1-M and slightly inclined toward wing base. Cell $1 \mathrm{mcu}$ small and subtriangular. $\mathrm{M}$ and Rs branching at 30\% from $1 \mathrm{~m}$-cu of the length between $1 \mathrm{~m}$-cu and $2 \mathrm{r}-\mathrm{rs}$. $1 \mathrm{cu}-\mathrm{a}$ and $2 \mathrm{cu}-\mathrm{a}$ distinct and reaching A. $1 \mathrm{cu}-\mathrm{a}$ in line with 1-M; and 2cu-a intersecting $\mathrm{Cu}$ and $\mathrm{Rs}+\mathrm{M}$ at the same point.

Hind wing with tubular veins $\mathrm{C}$ parallel with $\mathrm{Sc}+\mathrm{R}$ at base; $\mathrm{R}$ developed and $\mathrm{Rs}$ preserved; $\mathrm{M}+\mathrm{Cu}$ robust and forking at the basal section, $\mathrm{M}$ and 1-Cu long and distinct, 2-Cu long.

Right foreleg with only coxa and femur partially preserved. Right midleg with partial trochanter, spindle-shaped femur and partial tibia preserved. Right hindleg with partial coxa, trochanter trapezoidal and small, robust spindle-shaped femur, long tibia 
swollen distally with spurs, tarsi with five segments, basitarsus longest and two claws fixing the end of pretarsus.

Measurements (in mm). Mesosoma length 3.36, width 2.48; metasoma $>3.38$ long; lengths of the first to fifth metasomal segments are $0.34,0.51,0.72,0.94$, and 0.55 ; forewing length 6.52 , width $>3.05$.

Description of paratype. Body medium-sized (Fig. 2). Head oval and antennae filiform and thick, scape swollen and bell-shaped, only first and second flagellomeres preserved. Mesosoma, forewing and metasoma same as holotype, the end of terminal segment not preserved. Hind wing with tubular vein $\mathrm{C}$ parallel with $\mathrm{Sc}+\mathrm{R}$ at base, $\mathrm{M}+\mathrm{Cu}$ robust and forking at the basal section, $\mathrm{M}$ long, 1-Cu, 2-Cu distinct. Left foreleg and right midleg with only coxa and femur partially preserved. Left midleg with femur robust and tibia long, left hindleg with femur robust and spindle-shaped, long tibia swollen distally. Right hindleg with femur robust and spindle-shaped, tibia partially preserved.

Measurements (in mm). Body length $>14.6$; head length 1.89, width 1.53; mesosoma length 3.58, width 2.52; metasoma length 3.68; forewing length $>6.54$, width $>2.88$.

Comparison. This species can be assigned to Archaeohelorus Shih, Feng \& Ren, 2011 by its metasoma with six segments and the first segment narrow and transverse. Forewing 1-Rs as long as 1-M. Cell $1 \mathrm{mcu}$ small and subtriangular, $1 \mathrm{cu}-\mathrm{a}$ in line with 1-M; and 2cu-a intersecting $\mathrm{Cu}$ and $\mathrm{Rs}+\mathrm{M}$ at the same point. Compared with $A$. hoi, A. polyneurus has preserved hind wing with $\mathrm{Sc}+\mathrm{R}$ confluent with $\mathrm{C}$ and extended to costal margin, $\mathrm{R}$ developed. $\mathrm{M}+\mathrm{Cu}$ distinct and forking at the basal part, $\mathrm{M}$ and $\mathrm{Cu}$ robust; in forewing, cell $\mathrm{r}$ obtuse-angled triangular (vs. approximately right-angled triangular in $A$. hoi). Besides, $A$. polyneurus has a much larger body size than $A$. hoi, length of forewing $6.52 \mathrm{~mm}$ or $>6.54 \mathrm{~mm}$ (vs. $3.17 \mathrm{~mm}$ in $A$. hoi).

\section{Archaeobelorus tensus sp. $\mathbf{n}$.}

http://zoobank.org/84E4B637-E6E6-4799-929E-1536DA5213A5

http://species-id.net/wiki/Archaeohelorus_tensus

Figure 3

Etymology. The specific name "tensus" means stretching and long, referring to the shape of the forewing.

Type material. Holotype, CNU-HYM-NN2012056p/c, part and counterpart, dorsal view, male. A well-preserved almost complete body with antenna, forewings and part of legs and partial hind wings.

Locality and age. Jiulongshan Formation, Middle Jurassic, Daohugou Village, Shantou Township, Ningcheng County, Inner Mongolia, China.

Diagnosis. Forewing 2cu-a postfurcal with intersection of $\mathrm{Cu}$ and $\mathrm{Rs}+\mathrm{M}$. First abscissa of Rs (1-Rs) and basal section of $M(1-M)$ arched toward basal of wing. Hind wing with tubular veins $\mathrm{C}, \mathrm{Sc}+\mathrm{R}$, and Rs preserved. 

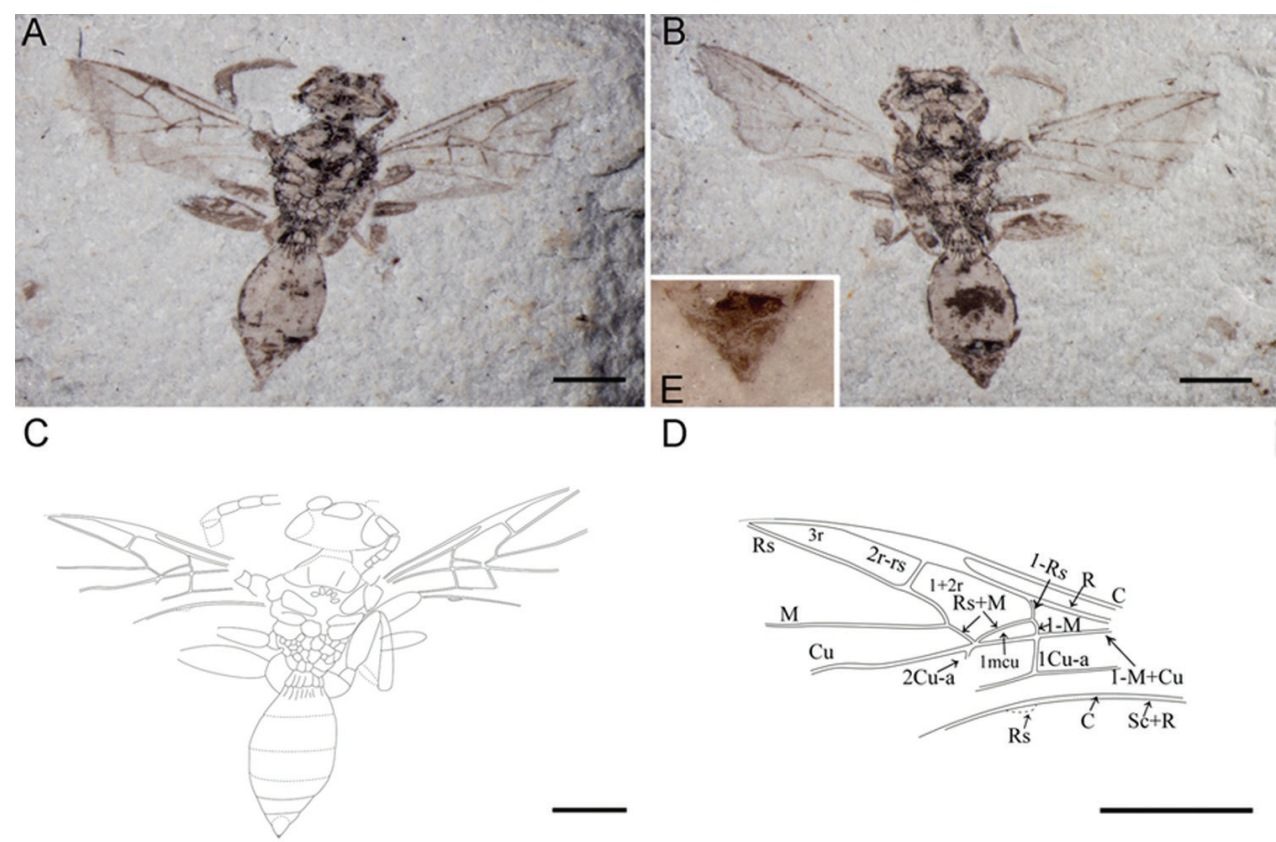

D

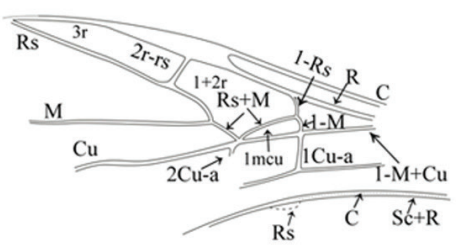

Figure 3. Holotype of Archaeohelorus tensus sp. n. CNU-HYM-NN-2012056 p/c, part and counterpart. $\mathbf{A}$ Photo of part $\mathbf{B}$ photo of counterpart $\mathbf{C}$ line drawing of part $\mathbf{D}$ line drawing of forewing $\mathbf{E}$ terminal segments of counterpart (under alcohol). Scale bars: $1 \mathrm{~mm}$. (Online figure in color.)

Description. A small adult specimen with a total body length of $4.4 \mathrm{~mm}$. Head suboval and large relative to mesosoma in width. Eyes large, and located at the both sides of the head.

Antennae filiform, thick, with 6 segments preserved on left and 5 segments preserved on right. Scape swollen and bell-shaped; pedicel short and quadrate; subsequent flagellomeres not well preserved.

Mesosoma subhexagonal and broader than head; pronotum narrower than head, short, probably covered by mesonotum; mesoscutum distorted in the middle and trapezoidal with notauli not distinct but preserved; tegula large and subtriangular; scutellum round with pits anteriorly; propodeum narrow, transverse and areolated.

Metasoma suboval with seven segments; first metasomal segment transverse with several longitudinal ridges; second segment trapezoidal with less longitudinal ridges anteriorly; other ones smooth; the male terminalia triangular, partially covered by the previous segment.

Forewing broad and subtriangular. Pterostigma long and acute apically, not widened beyond mid-length. C robust and extending near the apex of forewing. 2r-rs arising from basal one third of pterostigma, slightly longer than the width of pterostigma, and slightly oblique apicad. $\mathrm{R}$ robust and cell $\mathrm{r}$ closed with $\mathrm{C}, \mathrm{R}$ and 1-RS. Rs straight and intersecting with distal part of $\mathrm{C}$. Cell $1+2 \mathrm{r}$ longer and narrower relatively and six-sided 
surrounded by R, 1-Rs, 1-Rs+M, 2-Rs+M, 2-Rs, and 2r-rs. M+Cu straight and distinct; $\mathrm{M}$ and $\mathrm{Cu}$ distinct, almost straight. 1-Rs as long as 1-M and slightly inclined toward wing base. Cell $1 \mathrm{mcu}$ small, subtriangular and relatively slender with $2-\mathrm{M}+\mathrm{Cu} 4.3$ times as long as $1-\mathrm{M}$. M and Rs branching at 30\% from $1 \mathrm{~m}-\mathrm{cu}$ of the length between $1 \mathrm{~m}-\mathrm{cu}$ and 2r-rs. 1cu-a and 2cu-a distinct and reaching A. 1cu-a in line with 1-M; and 2cu-a postfurcal with Rs+M distinctly.

Hind wing, with tubular veins $\mathrm{C}$ parallel with $\mathrm{Sc}+\mathrm{R}$ at base, Rs short, intersecting distal part of $\mathrm{C}$.

Left foreleg, midleg and hindleg and right foreleg with only coxa and femur partially preserved, hind femur much thicker, nearly three times as long as wide; right midleg with partial spindle-shaped femur and partial tibia preserved, right hindleg with partial coxa, trapezoidal trochanter, robust spindle-shaped femur and relatively thin tibia and some parts of tarsus preserved.

Measurements (in mm): Body length 4.67, head length 1.39, width 0.68, mesosoma length 1.68, width 1.36; metasoma 2.23 long; lengths of metasomal segments are $0.20,0.39,0.48,0.38,0.25$ and 0.32 ; forewing length $>2.96$, width $>1.36$.

Remarks and comparison. This species is assigned to Archaeohelorus Shih, Feng \& Ren, 2011 by its seven separated metasomal segments, the first metasomal segment transverse with several longitudinal ridges. Forewing 1-Rs as long as 1-M. Cell $1 \mathrm{mcu}$ small and subtriangular, $1 \mathrm{cu}-\mathrm{a}$ in line with 1-M. Compared with $A$. hoi, $A$. tensus has preserved hind wing with tubular veins $\mathrm{C}, \mathrm{S}_{\mathrm{c}+\mathrm{R}}, \mathrm{R}$, and $\mathrm{Rs}$ preserved; in forewing, 2cu-a distinctly postfurcal with intersection of $\mathrm{Cu}$ and $\mathrm{Rs}+\mathrm{M}$ (vs. 2cu-a intersecting $\mathrm{Cu}$ and $\mathrm{Rs}+\mathrm{M}$ at the same point in $A$. hoi); cell $1 \mathrm{mcu}$ distinctly slender, 4.3 times as long as wide (vs. 2.4 times in $A$. hoi); 1-Rs and 1-M arched toward basal of wing (vs. 1 -Rs and 1-M straight in $A$. hoi). It also differs from $A$. polyneurus by its postfurcal 2cu-a, slender cell $1 \mathrm{mcu}$.

\section{Discussion}

In the vast and extensive Daohugou fossil insect collection ( $>200,000$ insect fossil specimens) at the Capital Normal University, only ten helorids are collected so far: two are Archaeohelorus polyneurus sp. n., one is Archaeohelorus tensus sp. n., and seven specimens are previously described Archaeohelorus hoi Shih, Feng \& Ren, 2011. It is likely that helorids might have been a very small group in the Middle Jurassic.

As a relict family, helorids have survived from the Middle Jurassic to now. Among all the fossil specimens, only $A$. polyneurus has distinct and complicated hind wing venation, which were unknown before. Therefore, the new findings are important supplement to helorid record and suggest that the trend for the morphological evolution of the Heloridae is as follows:

In the Middle Jurassic, $A$. polyneurus had forewing cell $\mathrm{r}$ obtuse-angled triangle, and hind wing venation clear and more complex $(\mathrm{C}$ and $\mathrm{Sc}+\mathrm{R}$ separated at base, $\mathrm{M}+\mathrm{Cu}$ short and robust, forking at the basal part, $\mathrm{M}$ and $\mathrm{Cu}$ distinct) and a much larger body 
(forewing length $>6.52 \mathrm{~mm}$ ). On the other hand, $A$. hoi and $A$. tensus had forewing cell $\mathrm{r}$ approximately right-angled triangular, and hind with simplified venation (only $\mathrm{C}$ and $\mathrm{Sc}+\mathrm{R}$ and/or $\mathrm{R}$ preserved) and smaller body (forewing length $\approx 3 \mathrm{~mm}$ ). In the Late Jurassic to the Early Cretaceous, Spherogaster coronata Zhang \& Zhang, 2001 had hind wing with only $\mathrm{C}, \mathrm{R}$ and $\mathrm{M}$ present, costal area extremely narrow, and a much larger body size with forewing length of $12 \mathrm{~mm}$. In extant helorids, forewing cell $\mathrm{r}$ approximately right-angled triangular, and hind wings have tubular veins $\mathrm{C}$ and $\mathrm{Sc}+\mathrm{R}$ and nebulosus veins of $\mathrm{M}+\mathrm{Cu}, \mathrm{M}, \mathrm{Cu}$ and $\mathrm{A}$ (Goulet and Huber 1993). The body size is small with forewing about $3.3 \mathrm{~mm}$ long (van Achterberg 2006).

\section{Acknowledgments}

We are sincerely grateful to Qiang Yang and Taiping Gao (College of Life Sciences, Capital Normal University) for their valuable comments and suggestion on the manuscript. This work was supported by the National Basic Research Program of China 973 Program Grant 2012CB821906; National Natural Science Foundation of China Grants, 31230065 and 41272006; Great Wall Scholar and KEY project of Beijing Municipal Commission of Education (grant KZ201310028033), Program for Changjiang Scholars and Innovative Research Team in University.

\section{References}

Engel MS, Ren D (2008) New snakeflies from the Jiulongshan Formation of Inner Mongolia, China (Raphidioptera). Journal of the Kansas Entomological Sociaty 81: 188-193. doi: 10.2317/JKES-802.19.1

Grimaldi DA, Engel MS (2005) Evolution of the insects. Cambridge University Press, New York, NY, $421 \mathrm{pp}$.

Gu JJ, Montealegre ZF, Robert D, Engel MS, Qiao GX, Ren D (2012) Wing stridulation in a Jurassic katydid (Insecta, Orthoptera) produced low-pitched musical calls to attract females. Proceedings of the National Academy of Sciences USA 109(10): 3868-3873. doi: $10.1073 /$ pnas. 1118372109

He JH (1992) Iconography offorest insects in Hunan China. Science Press, Hunan, China, 1293-1296. [in Chinese with English summary]

Huber JT, Sharkey MJ (1993) Chapter 3. Structure. In: Goulet H, Huber JT (Eds) Hymenoptera of the world: an identification guide to families. Research Branch Agriculture Canada Publication, Ottawa, ON, Canada, 13-59.

Huang JD, Ren D, Sinitshenkova ND, Shih CK (2008) New fossil mayflies (Insecta: Ephemeroptera) from the Middle Jurassic of Daohugou, Inner Mongolia, China. Insect Science 15: 193-198. doi: 10.1111/j.1744-7917.2008.00200.x

Li YJ, Nel A, Ren D, Pang H (2011) A new genus and species of hawker dragonfly of uncertain affinities from the Middle Jurassic of China (Odonata: Aeshnoptera). Zootaxa 2927: 57-62. 
Liu LX, Shih CK, Ren D (2012) Two new species of Ptychopteridae and Trichoceridae from the Middle Jurassic of northeastern China (Insecta: Diptera: Nematocera). Zootaxa 3501: 55-62.

Liu YS, Sinitshenkova ND, Ren D, Shih CK (2011) Pronemouridae fam. nov. (Insecta: Plecoptera), the stem group of Nemouridae and Notonemouridae, from the Middle Jurassic of Inner Mongolia, China. Palaeontology 54(4): 923-933. doi: 10.1111/j.14754983.2011.01063.x

Lu Y, Yao YZ, Ren D (2011) Two new genera and species of fossil true bugs (Hemiptera: Heteroptera: Pachymeridiidae) from northeastern China. Zootaxa 2835: 41-52.

Rasnitsyn AP (1986) Order Vespida (Hymenoptera). In: Insects in the Early Cretaceous Ecosystem of the West Mongolia. Transactions of the Joint Soviet-Mongolian Paleontological Expedition 28: 154-164. [in Russian]

Rasnitsyn AP (1990) Hymenoptera. In: Rasnitsyn AP (Ed) Late Mesozoic insects of Eastern Transbaikalia. Transactions of the Paleontological Institute, Academy of Sciences of the USSR 239: 177-205. [in Russian]

Rasnitsyn AP, Zhang HC (2010) Early evolution of Apocrita (Insecta, Hymenoptera) as indicated by new findings in the Middle Jurassic of Daohugou, Northeast China. Acta Geologica Sinica (English Edition) 84(4): 834-873. doi: 10.1111/j.1755-6724.2010.00254.x

Ren D, Gao KQ, Guo ZG, Ji SA, Tan JJ, Song Z (2002) Stratigraphic division of the Jurassic in the Daohugou Area, Ningcheng, Inner Mongolia. Geological Bulletin of China 21: 584-591.

Ren D, Labandeira CC, Santiago-Blay JA, Rasnitsyn AP, Shih CK, Bashkuev A, Logan MAV, Hotton CL, Dilcher D (2009) A probable pollination mode before angiosperms: Eurasian, long-proboscid scorpionflies. Science 326(6): 841-847.

Ren D, Shih CK, Gao TP, Yao YZ, Zhao YY (2010) Silent Stories-Insect Fossil Treasures from Dinosaur Era of the Northeastern China. Science Press, Beijing, China.

Rohdendorf BB (1938) Mesozoic Diptera from Karatau. I Brachycera and some Nematocera. Trudy Paleontologicheskogo Instituta Academii Nauk SSSR 7: 29-67.

Shi CF, Yang Q, Ren D (2011) Two new fossil lacewing species from the Middle Jurassic of Inner Mongolia, China (Neuroptera: Grammolingiidae). Acta Geologica Sinica 85: 482-489. doi: 10.1111/j.1755-6724.2011.00416.x

Shi XQ, Zhao YY, Shih CK, Ren D (2013) New fossil helorid wasps (Insecta, Hymenoptera, Proctotrupoidea) from the Jehol Biota, China. Cretaceous Research 41: 136-142. doi: 10.1016/j.cretres.2012.12.001

Shih CK, Feng H, Liu CX, Zhao YY, Ren D (2010) Morphology, phylogeny, evolution and dispersal of pelecinid wasps (Hymenoptera: Pelecinidae) over 165 million years. Annals of the Entomological Society of America 103: 875-885. doi: 10.1603/AN09043

Shih CK, Feng H, Ren D (2011) New fossil Heloridae and Mesoserphidae wasps (Insecta, Hymenoptera, Proctotrupoidea) from the Middle Jurassic of China. Annals of the Entomological Society of America 104 (6): 1334-1348. doi: 10.1603/AN10194

Tan JJ, Ren D, Shih CK, Yang XK (2012) New schizophorid fossils from China and possible evolutionary scenarios for Jurassic archostematan beetles. Journal of Systematic Paleontology. doi: 10.1080/14772019.2011.637515 
van Achterberg C (2006) European species of the genus Helorus Latreille (Hymenoptera: Heloridae), with description of a new species from Sulawesi (Indonesia). Zoologische Mededelingen Leiden 80: 1-12.

Wang M, Shih CK, Ren D (2012) Platyxyela gen. nov. (Hymenoptera, Xyelidae, Macroxyelinae) from the Middle Jurassic of China. Zootaxa 3456: 82-88.

Wang Y, Shih CK, Jacek S, Ren D (2012) New fossil palaeontinids (Hemiptera, Cicadomorpha, Palaeontinidae) from the Middle Jurassic of Daohugou, China. Alcheringa. doi: 10.1080/03115518.2012.690972

Wang YJ, Liu ZQ, Wang X, Shih CK, Zhao YY, Engel ES, Ren D (2010) Ancient pinnate leaf mimesis among lacewings. Proceedings of the National Academy of Sciences of the United States of America 107(37): 16212-16215. doi: 10.1073/pnas.1006460107

Wang YJ, Labandeira CC, Shih CK, Ding QL, Wang C, Zhao YY, Ren D (2012) Jurassic mimicry between a hangingfly and a ginkgo from China. Proceedings of the National Academy of Sciences of the United States of America 109(50): 20514-20519. doi: 10.1073/ pnas. 1205517109

Wei DD, Shih CK, Ren D (2012) Arcofuzia cana gen. et sp. n. (Insecta, Blattaria, Fuziidae) from the Middle Jurassic sediments of Inner Mongolia, China. Zootaxa 3597: 25-32.

Zhang HC, Zhang JF (2001) Proctotrupoid wasps (Insecta, Hymenoptera) from the Yixian formation of western Liaoning Province. Acta Micropalaeontologica Sinica 18: 11-28.

Zhang JF (1992) Two new genera and species of Heloridae (Hymenoptera) from Late Mesozoic of China. Entomotaxonomia 14: 222-228. 